\title{
DA IMPORTÂNCIA DOS MERCADOS PARA AS RELIGIÓES AFRO-BRASILEIRAS
}

THE IMPORTANCE OF MARKETS FOR AFRO-BRAZILIAN RELIGIONS

\section{Adalberto Ojuobá Pernambuco ${ }^{1}$}

$\mathrm{Na}$ África, berço da Religião dos Orixás, o mercado representava e ainda representa, nas aldeias, um ponto central de convergência de toda a população em determinados dias da semana.

As cidades africanas tinham como característica o nascimento do mercado local concomitantemente com a construção das primeiras casas, localizando-o, invariavelmente, no centro da aldeia. Era um lugar de reunióes onde pessoas, a par do exercício do comércio, tinham a oportunidade de se encontrar, trocar ideias, abordar os mais variados temas e dirigir suas dúvidas sobre isto ou aquilo. Ali faziam ponto os sacerdotes de Ifá, os Babalawos, aguardando consulentes para, se necessário, encaminha-los aos Templos, a fim de ouvirem Ifá, o Orixá do Destino e, portanto, da adivinhação. Efetuavam-se transaçôes visando a aquisição de animais destinados ao sacrifício ou de materiais religiosos não fabricados na região. Tais operaçôes eram efetuadas no sistema do escambo ou pela aquisição em moeda corrente, sempre não nos esquecendo de que era representada pelos cawris, aqui mais conhecidos por búzios.

O mercado sempre foi o começo e assim o será ao longo dos anos, quando resiste à evolução dos séculos e continua a manter sua predominância sobre todas as demais criaçóes modernas do homem, inclusive os supermercados, isto por que mantém a sua característica agregadora. Podemos notar que os frequentadores do mercado agregam-lhe um vínculo familiar, ao contrário dos demais estabelecimentos, cujas relaçóes entre os que os visitam são totalmente impessoais. Insuperável elemento aglutinador dos seres

1 Breve biografia do autor presente na abertura deste debate, na apresentação de Carvalho, Veras e Emil. 
humanos e das comunidades, sua influência se faz sentir pelo fato de ensinar os homens a lidarem com seus semelhantes, respeitá-los e demonstrar-lhes fraternidade. Principalmente para nós, povo da língua portuguesa, único oriundo da Europa que manteve em seu idioma, proveniente do latim, o seu dia-a-dia vinculado ao mercado e tomando-o como fonte de referência. Senão vejamos: enquanto todas as demais línguas, inclusive nossas irmãs de berço, associam os dias da semana ao nome dos astros, a nossa semana é marcada pelos dias de mercado (feiras em Portugal) excluídos o domingo, dia do Senhor em todos os idiomas, e o sábado que seria o sétimo dia, o dia do descanso, o Shabat judaico.

É curioso considerar, no entanto, que na África, principalmente entre os Iorubas, a semana é constituída de apenas quatro dias e que são até hoje respeitados conforme puderam constatar dois dos grandes estudiosos da Religiáo Africana em nosso meio, Roger Bastide e Pierre Verger (O artigo que escreveram sobre os mercados africanos, Contribuition à l'Étude Sociologique dês Marches Nagô du Bas-Dahomey, é roteiro indispensável aos que querem se dedicar ao estudo deste assunto, segundo nos informa Antônio Olinto que visitou a África com essa finalidade e em companhia de Zora Seljam, outra grande antropóloga dedicada ao nosso Culto).

O primeiro dia é o Ojó Awô, dedicado a Ifá e Exu, o chamado dia do segredo; o segundo, Ojó Ogum, dedicado ao Orixá dos metais; o terceiro, Ojó Jacutá, dedicado a Xangô, Orixá do trovão, e, finalmente, o quarto Ojó Obatalá, dedicado ao maior dos Orixás, Oxalá.

O quatro é um número sagrado para os africanos e nós vamos constatar, com surpresa, que é uma constante no Mercado Municipal de Porto Alegre. Seu corpo principal é constituído de dois quadrados, um sobreposto ao outro: quatro são as entradas que lhe dão acesso, quatro as vias em que circulam os seus frequentadores e a banca central se apresenta como um octaedro, ou seja, duas vezes o número quatro. Tudo isto nos leva a afirmar que houve uma interferência africana, ainda que sutil, na sua concepçáo como edifício. (Constatamos, com alegria que o projeto de sua reforma 
não vai interferir no básico da construção que será mantido e, portanto, preservados os fundamentos basilares do prédio). ${ }^{2}$

Esse interesse do Povo de Religião pelo mercado deve causar surpresa aos leigos. Ainda que muitos digam que se trata da preservação de uma obrigação "sentada" pelo Príncipe Custódio, naquele local, entendemos que o interesse maior seja o de conservarmos a casa do Bará (Exu) em toda a sua plenitude. Sim, porque o mercado é uma das moradas daquela entidade e tanto o é que, no dizer de Vogel, Silva Mello e Pessoa de Barros, em seu curioso e extraordinário livro "A Galinha d'Angola”, a viagem ao mundo afro-brasileiro começa no mercado. Tanto nos da Bahia, em Pernambuco ou no Ver-o-Peso de Belém do Pará, em todos eles encontraremos tudo o que se diga de respeito ao material necessário para a feitura das obrigaçóes, qualquer seja a modalidade do culto: Nação, Candomblé, Xangô, Tambor de Mina, Catimbó, Macumba ou Babaçuê.

As trocas efetuadas nesses mercados, desde as de mercadoria até aquilo que diz respeito à vida comum de nosso povo, como intrigas políticas e amorosas, rixas e amizades, encontros, transaçóes, escândalos e novidade, tudo isto significa movimento, pois troca é movimento, e este é transitividade e, assim sendo, se subordinam a Exu (Bará) "o grande princípio dinâmico na cosmovisão do Candomblé” (e da nossa Nação). Portanto, não é de se estranhar que o Bará tenha agregado em seu nome o título de Olóojá que significa "dono do mercado".

Se aqui já não mais existe, em quase todos os lugares vamos encontrar à entrada do mercado um assentamento sumário onde são depositados os tributos devidos àquele que é o senhor "dos limiares e das passagens", com o que ele nos auxiliará na decisão do que é melhor e nos obterá um preço mais razoável para nossas compras.

2 Após a reforma realizada na década de 1990, a banca central do Mercado Público de Porto Alegre foi removida, dando lugar a uma encruzilhada cujo centro foi adornado com um mosaico demarcando o local onde se encontraria o assentamento do Bará. 
É evidente que hoje, ou melhor, desde a sua primeira reforma, o Mercado Público de Porto Alegre, atendendo aos reclamos do progresso, deixou para trás algumas das suas características religiosas e extinguiu várias tradiçôes africanas ali em uso. É verdade, também, que as recordaçóes não morrem, mas permanecem trazendo-nos à lembrança os tempos de antanho em que negros africanos, emersos da escravidáo, ocupavam os seus corredores. Assim sendo, as floras do mercado tinham todo o necessário para o nosso culto, hoje já náo ostentam aquela variedade que lhes era exigida pelo fato de ali se concentrarem todas as compras. O surgimento de supermercados e de firmas especializadas em bijuterias e até mesmo armarinhos, tiraram do seu âmbito exclusivo mercadorias como amendoins, gengibre, sagu, tapioca, favas e sementes de todos os tipos, azeite doce ou de dendê, cocoda-Bahia, mel, melado, pimenta malagueta e do reino, contas, miçangas, guizos, corais, pulseiras, colares, brincos, pingentes, toda sorte de tecidos, cadarços, rendas, fitas, gregas, botôes, fechos e sianinhas. Restaram apenas as resinas e essências como o estoraque, a alfazema, o benjoim, o patchuli, a mirra, o almíscar e o alecrim, bem como os produtos de perfumarias tais como sabóes, sabonetes, colônias, perfumes e bálsamos e também as folhas empregadas nos banhos ritualísticos como arruda, alecrim, manjericão, malva cheirosa e várias outras que compóem o reino de Ossayn.

O mercado é o início obrigatório para o estudo dos cultos afro-brasileiros, incontestavelmente, se considerarmos que o aspirante à iniciação recebe uma lista de todo o material necessário e, sempre acompanhado de um iniciado mais antigo, desloca-se para lá em busca de alguma coisa que para ele, neófito, se constitui em algo incompreensível. Daí o indispensável acompanhamento de um irmáo mais experiente. Após essa primeira passagem, voltará várias vezes ao local, umas visando à aquisição de material para "trabalhos" e outras por exigência da própria ritualística. Ao seu término e como complemento, é feito, aqui no Rio Grande do Sul, o que chamamos de "passeio" e que inclui, em seu roteiro, uma visita ao mercado. Cada vez em que é feito o que denominamos de reforço, o "passeio" é novamente realizado com idêntico itinerário. ( $\mathrm{Na}$ África a 
passagem pelo mercado é feita também quando do desencarne dos praticantes do culto, rotina abolida em nosso país).

Antigamente as casas especializadas em artigos de religiáo estavam todas localizadas no mercado e seus proprietários eram pessoas ligadas intimamente ao culto, mesmo que não iniciadas. Assim sendo, tinham condiçôes de, pelos pedidos formuladores pelas Casas, não só saberem a Nação nelas cultuadas, como também avaliarem a competência dos seus dirigentes com referência às mais variadas cerimônias a serem efetuadas. Hoje já não se encontram mais pessoas com tais qualidades, parecendo-nos que o velho Bandeira, antigo proprietário de uma das floras localizadas em nosso Mercado Municipal, foi o último remanescente do grupo.

Como vimos, a importância do mercado dentro da vida das casas que se dedicam aos cultos afro-brasileiros é insofismável e só lamentamos que o progresso venha nos afastando do seu convívio sadio e puro que empreendemos, ao início da nossa caminhada, como Filho-de-Orixá.

Tudo isso, porém, náo justifica o esquecimento de que, ao entrarmos em nosso mercado, por mais modernizado que ele esteja, estamos ingressando no reino do Bará (Exu) Olóoja. E náo nos custa pedirmos a ele que os víveres que guarda sirvam para minorar a fome de nossos semelhantes menos afortunados.

Recebido em: 27/10/2018

Aprovado em: 27/10/2018 
